\title{
Physicochemical indicators of the influence of a lined municipal landfill on groundwater quality: a case study from Poland
}

\author{
Grzegorz Przydatek ${ }^{1}$ (D) . Włodzimierz Kanownik ${ }^{2}$
}

Received: 15 February 2021 / Accepted: 9 June 2021 / Published online: 24 June 2021

(c) The Author(s) 2021

\begin{abstract}
The paper aims to determine the most significant physicochemical indicators of the effects that a lined landfill in southern Poland has had on groundwater quality. The results of the tests of groundwater and leachate water from the landfill for the period 2009 to 2016 were subjected to a detailed statistical analysis based on the 10 physicochemical parameters. A factor analysis was conducted considering the European Union and national requirements for landfills using analytical and statistical tools. The leachate contamination indicators from a landfill were analysed to reveal their interaction with the groundwater. The assessment indicated that there was an elevated and statistically significantly higher electrical conductivity and copper and total organic carbon concentrations in groundwater hydraulically downgradient of the landfill. The assessment also indicated that there were significant differences in the correlations between chemical parameters downgradient of the landfill and that there was a trend of increasing concentrations of some chemical constituents in groundwater. The adverse effects of the landfill were due to the deposited amount of waste exceeding $10 \mathrm{Mg}$ per day. The impact was noticeable despite low and decreasing concentrations of heavy metals $(\mathrm{Hg}, \mathrm{Cu}, \mathrm{Cd}, \mathrm{Pb}$ and $\mathrm{Zn})$ in the leachate. The deterioration of the chemical state of the groundwater in the landfill vicinity could result in the extended time of pollutant migration or mass transport in the irrigated soil medium due to the limited efficiency of the leachate intake system or sealing screen after more than 20 years of landfill operation.
\end{abstract}

Keywords Municipal waste $\cdot$ Landfill $\cdot$ Water $\cdot$ Impact $\cdot$ Leachate

\section{Introduction}

In the twenty-first century, landfills around the world continue to be an important part of waste management. In Poland, which is ranked sixth among the European Union countries in terms of population, 278 landfills were in use at the end of 2019 (Statistics Poland 2019). Their locations, construction details and method of operation are subject to regulation in the country. The regulation and management of landfills in Poland also consider the hydrological and geotechnical conditions for the construction and operation of these facilities to minimise the potential negative effects

Grzegorz Przydatek

gprzydatek@pwsz-ns.edu.pl

1 Engineering Institute State University of Applied Sciences in Nowy Sącz, Zamenhofa 1a St., 33-300 Nowy Sącz, Poland

2 Faculty of Environmental Engineering and Land Surveying, University of Agriculture in Krakow, Ave. Mickiewicza 24-28, 30-059 Kraków, Poland of stored waste on the environment (Przydatek 2019b). The existence of such facilities results from the fact that the storage process remains one of the preferred solutions in the waste management hierarchy. Despite the application of the latest technical solutions, landfills as engineering facilities still pose a serious threat to the aquatic environment (Han et al. 2016). This is because chemical processes in the mass of deposited waste can produce landfill gas and leachate that contains environmentally harmful concentrations of some dissolved chemical constituents (Abd El-Salam and AbuZuid 2015; Przydatek and Kanownik 2019).

The chemical composition of leachate water is determined by the composition of the waste, the way it is used, the age of the landfill, the availability of oxygen, the hydrogeological conditions and the ambient temperature and precipitation (Ilies and Mavinic 2001; Chen 2006; Longe and Balogun 2009; Regadío et al. 2013; Przydatek 2019c). Sari et al. (2013) divided leachates into young, middle-aged and mature, which is considered important in the choice of technology to neutralise them because, due to its toxic content, 
leachates pose a threat to surface water, groundwater and the soil (Barbieri et al. 2014; Naveen et al. 2017).

Some researchers (Gworek et al. 2016; Przydatek 2019c) have classified leachates as one of the main sources of heavy metal transfer to the environment. Heavy metals are problematic because of their negative effect on the environment. The migration of leachates from landfills poses a high risk to groundwater resources if not adequately protected (Patil et al. 2013). The risk of groundwater contamination by leachates from landfills requires that their composition be identified at each stage of operation and, in particular, exploitation, as groundwater is usually considered to be of good natural quality due to its geological environment (MacDonald and Calow 2009; Przydatek and Kanownik 2019). The control of the municipal landfill site remains an important aspect due to the potential threat of leachates to the surrounding water environment as a result of changes in quality (Xie et al. 2015).

The monitoring of leachates from landfills provides early identification of the risk, which may contribute to reducing the damage to both people and the environment (Salem et al. 2008). Therefore, one of the important activities aimed at recognising the environmental effects of landfilled waste with different physical and chemical properties following the guidelines of Council Directive 1999/31/EC of 26 April 1999 is to comply with environmental laws and regulations concerning the monitoring of pollution in the area of landfills, considering the water environment, including the leachate water composition (Przydatek and Kanownik 2019). When assessing the effects of landfill sites on the aquatic environment, the use of carefully selected statistical tools and variables can be very helpful, as confirmed by some researchers (Aziz et al. 2018; Farzaneh et al. 2021; Przydatek 2021).

The appropriate operation of the landfill and, as a result, maintaining a low level of leachate water in the waste deposit is a basic requirement for water protection in the vicinity of landfills. This is important because groundwater is the main source of water supply in many urban and rural areas (Singh et al. 2016).

The study aimed to assess the impact of an lined municipal waste landfill in Poland on the physicochemical condition of groundwater in its vicinity using selected statistical tools. The landfill site that was investigated was operational during the period 2009 to 2016.

\section{Characteristics and geological setting of the landfill}

The selected municipal landfill has been operating since 1985 in the area of city Tarnow and is one of the largest in southern Poland N: $50^{\circ} 02^{\prime} 35^{\prime \prime}$ E: $21^{\circ} 01^{\prime} 55^{\prime \prime}$ (Fig. 1). The land surface in the area of the landfill is gently undulating

Fig. 1 Location of landfill site

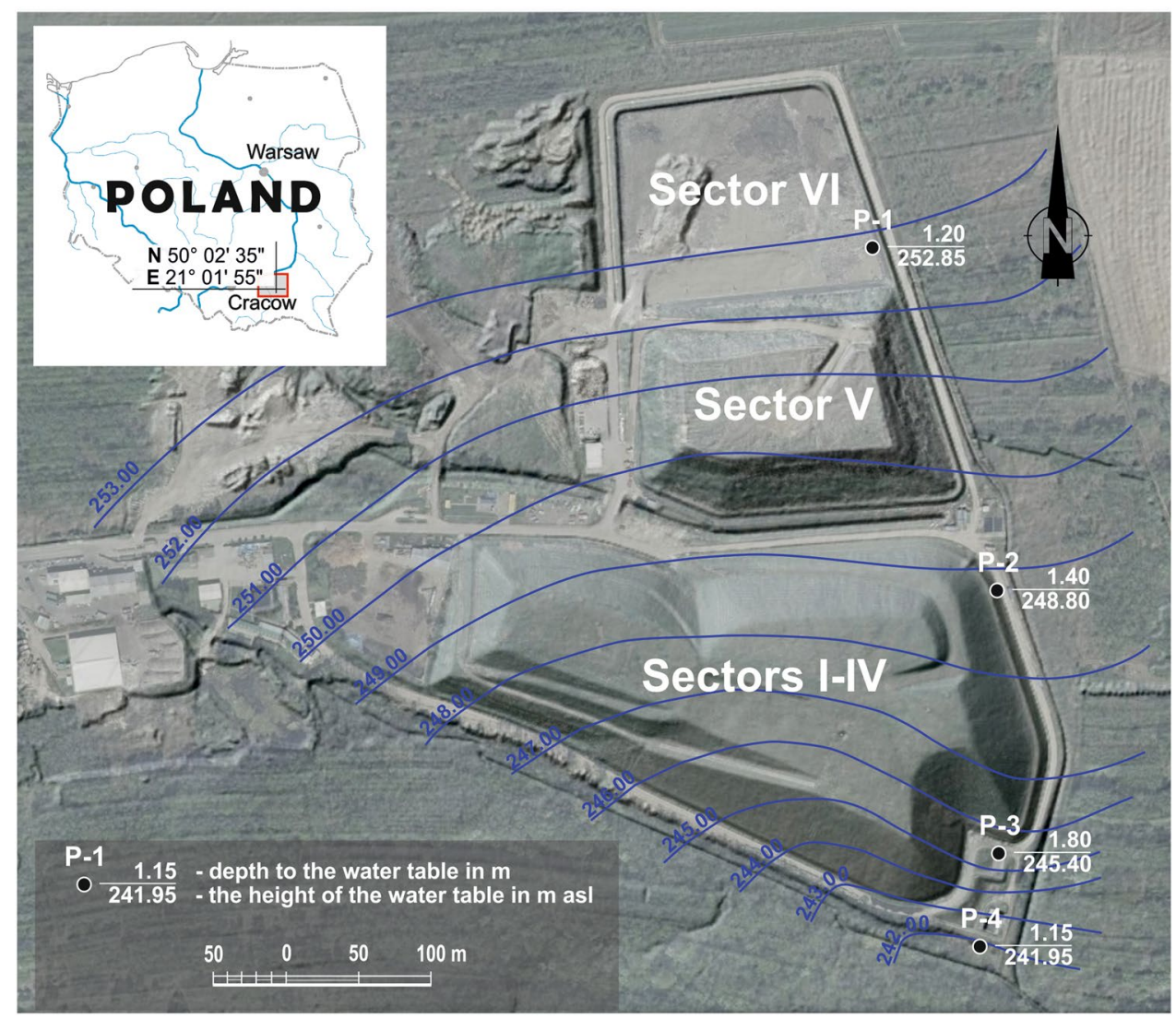


and sloping with an average slope of 5\% to the east and south east. The range of the landfill site elevation is between 251.35 and $257.22 \mathrm{~m}$ asl.

The landfill is located in the area of the pre-Carpathian subsidence filled with the Tertiary Krakowickie Clay, on which Quaternary formations have settled. The Tertiary clay has a thickness exceeding $2000 \mathrm{~m}$ and is deposited in the area of the landfill at a depth of 2-5 m (Przydatek 2019b). Hirschberg (1993) showed that the capacity of clays restricts the development of leachate plumes in clay. The Quaternary formations are formed by Pleistocene glacial accumulation sediments formed as till clay and Holocene sediments formed as clays, sandy clays and locally occurring noncohesive sediments. There is one aquifer in the area of the landfill. It is at the quaternary groundwater level associated with a small interlayer and the occurrence of silty-loam sediment that overlies the Krakowicki Clay.

The direction of the groundwater flow was from northwest to southeast. The landfill under study covers an area of almost 9 ha, consisting of six sectors, including one currently in operation. Sectors I-IV were in operation until the end of 2009, and Sector V stopped service in 2018 and is undergoing reclamation. Sector VI of the landfill has been in use since 2019 (Fig. 1).

Sectors II and III are sealed on the underside with only a natural barrier made of loams and clays and on the top, they are sealed with a geomembrane. Further, Sectors I, IV, V and VI have a 2.0-mm-thick HDPE geomembrane seal on the bottom of the basin, which is on a natural layer of a geological barrier consisting of a layer of loam and sandy clay. The geomembrane is protected against mechanical damage by a geotextile with a layer of 0.5 -m-thick gravel.

To protect the soil and water environment, leachates from four inactive sectors and one active sector are taken by siphons with a diameter of $\varnothing 225 \mathrm{~mm}$ and a collecting drain with a diameter of $\varnothing 315 \mathrm{~mm}$, from where they go into a tank with a usable capacity of $336 \mathrm{~m}^{3}$. This tank is equipped with two open chambers. The first chamber is a settling tank and the second is equipped with a grate for leachate aeration. The leachates captured on the landfill site after the treatment process go to the sewage treatment plants through the sanitary sewage system.

Over $30,000 \mathrm{Mg}$ of municipal waste with a daily quantity exceeding $10 \mathrm{Mg}$ was deposited at the analysed landfill site during the eight years under study. Recently, residues from the recovery of raw material waste have been deposited as a result of secondary segregation conducted in the waste processing plant adjacent to the analysed facility. This method of waste management has helped reduce the amount of waste deposited in the landfill facility, with particularly for organic waste.

Waste materials at the storage site are placed both below and above ground with heavy equipment. During operation, waste is systematically poured over and a layer of inert waste and after the last layer is built, it is covered with humus at a thickness of $0.15 \mathrm{~m}$, which is treated as an initial element of reclamation (Przydatek 2019b).

The landfill sectors are actively degassed using 76 wells. The landfill gas is taken cumulatively in one station in an active way with recovery in the form of cogenerated energy (Przydatek 2019b). According to Faitli et al. (2015), disposal of landfill gas with this energy recovery is a significant priority. Following the structural classification developed by Aziz et al. (2018), landfill construction indicates that such a facility can be classified as anaerobic.

\section{Materials and methods}

The test results of the physicochemical parameters of groundwater and leachate samples, meteorological data and the number of leachate samples collected over a period of eight years were used to conduct a statistical analysis and to draw conclusions aimed at demonstrating principal factors that influence groundwater quality in in the immediate vicinity of a municipal landfill (Przydatek and Kanownik 2019).

\section{Assessment of the landfill water balance}

In this paper, the quarterly volume of leachate and the pluviothermal conditions (quarterly sum of precipitation and average quarterly air temperature) were determined. Meteorological data were obtained from the meteorological station of the Institute of Meteorology and Water Management (N: $\left.50^{\circ} 1^{\prime} 59^{\prime \prime}, \mathrm{E}: 20^{\circ} 59^{\prime} 4^{\prime \prime}\right)$ located near the landfill.

\section{Physicochemical methodology of water tests}

The electrical conductivity of groundwater and landfill leachate samples was determined in the field after the collection of each sample using a portable multifunctional meter. This device was calibrated each time before the tests were conducted. Each result was taken based on the average of three measurements (Przydatek 2019a).

The samples for metal analysis were filtered to $0.45 \mu \mathrm{m}$ in the field and placed in acid-washed bottles. The water samples were placed in sterilised plastic containers and delivered on the same day to an accredited testing laboratory for according to accredited quality and reliability methods. Then the collected samples were transported to the laboratory under the required cooling conditions (APHA 2007). The minimum volume of samples was $500 \mathrm{ml}$.

The samples of groundwater from piezometers located in the surround of the landfill site and the samples of the leachate gathered in the collection well at the landfill site were collected once a quarter from 2009 to 2016. Groundwater 
for laboratory tests was collected after the water from the piezometers was pumped out. The water was taken from four piezometers, including one piezometer (P-1) located hydraulically upgradient of the landfill which corresponds to the requirements (Regulation ME 2013). It is the reference level (the so-called background) for water quality comparisons for three piezometers (P-2, P-3 and P-4) located near the landfill on the groundwater outflow side, which were used to whether leachate from the landfill facility had caused groundwater contamination (Fig. 1). Raw leachate samples from the tank were taken from the drainage located at the bottom of the basin of individual sections of the landfill (including from one active cell).

The suite of chemical parameters that were analysed in groundwater and leachate samples included three general physicochemical parameters: $\mathrm{pH}$, total organic carbon (TOC) and electrical conductivity (EC); six inorganic elements: cadmium $(\mathrm{Cd})$, hexavalent chromium $(\mathrm{Cr})$, copper $(\mathrm{Cu})$, lead $(\mathrm{Pb})$, mercury $(\mathrm{Hg})$ and zinc $(\mathrm{Zn})$; and one group of organic chemical constituents: polycyclic aromatic hydrocarbons (PAHs). Some researchers (Baun and Christensen 2004; Przydatek and Kanownik 2019) have also included $\mathrm{Cd}, \mathrm{Cr}^{+6}, \mathrm{Cu}, \mathrm{Hg}, \mathrm{Pb}$ and $\mathrm{Zn}$ as typical heavy metal elements contained in leachates.

In an accredited chemical laboratory, the concentrations of $\mathrm{Cr}^{+6} \mathrm{Cd}, \mathrm{Cu}, \mathrm{Hg}, \mathrm{PAH}$ and TOC were determined. The concentrations of heavy metals $\mathrm{Cd}, \mathrm{Cr}^{+6} \mathrm{Cu}$, were determined using Atomic Absorption Spectroscopy (AAS). Moreover, the concentrations of TOC and PAHs were determined. For the TOC determination, a spectrophotometer was used to measure the absorbance value, while the PAHs were determined using the HPLC method with fluorescence detection after liquid-liquid extraction. In the examined samples, $\mathrm{Hg}$ was determined using the CVAAS technique (Almeida et al. 2016).

The laboratory analyses were conducted twice and repeated only when the limit values were exceeded. The results were outside the calibration curve or the abnormal results were obtained for a given matrix. The content of the demonstrated chemical contamination of the leachate was determined to the nearest $\mu \mathrm{g} / \mathrm{L}$ (Przydatek 2019a).

The results of the tests on the water leaking from the landfill have been compared with the values included in the Regulation of the Minister of Maritime Economy and Inland Navigation (MMEIN) of 12 July 2019 on substances particularly harmful to the water environment and the conditions to be met when discharging wastewater into water or soil (Regulation MMEIN 2019a).

The quality of groundwater in the piezometers was determined following the Regulation of the Minister of Maritime Economy and Inland Navigation of 11 October 2019 on the criteria and method of assessment of the status of groundwater bodies (Regulation MMEIN 2019b). In addition, the results of the tested waters were compared with the limit values specified by WHO (2017) for drinking water. Han et al. (2016) analysed the impact of a landfill on the aquatic environment, using national and international standards to assess the potential for negative effects on environmental receptors.

The determination of whether concentrations of specific contaminants in groundwater and leachate samples from the landfill exceeded the relevant water quality guideline limits was based on the arithmetic mean value for each tested physicochemical parameter (Przydatek 2019a).

\section{Statistical methods of the analysis results}

\section{Groundwater and leachate samples}

For the tested indicators of leachate contamination, the following statistical parameters were determined: the minimum and maximum values, arithmetic mean and standard deviation values (Atta et al. 2015; Przydatek and Kanownik 2019). For the calculation of the values of statistical parameters, the result of the measurement at half of the limit of quantification was used where the values of the water indicators in a given sample were below the limit of quantification defined by a multiple of the detection rate. The collected results of the physicochemical parameters of groundwater samples from piezometers were used for statistical analysis to draw conclusions assessing the influence of the lined landfill on groundwater quality near the landfill facility. The nonparametric Kruskal-Wallis test and multiple comparisons of mean ranks were used to estimate the significance of the differences in the concentrations of the examined groundwater indicators upgradient and downgradient of the municipal landfill. Nonparametric tests were applied due to the lack of a normal distribution of most of the analysed physicochemical indicators according to the results of the Shapiro-Wilk test and the inequality of the variance determined using the Fisher-Snedecor test. For groundwater physicochemical indicators, significant differences between piezometers, extreme values, median and quartile spacing are presented in box plots (Figs. 2, 3).

To determine the effect of the municipal landfill on the physicochemical state of groundwater, the correlation between the physicochemical parameters of the leachate and groundwater samples from downgradient of the landfill were determined (Przydatek and Kanownik 2019). Correlation analysis is a preliminary descriptive technique to estimate the degree of association between the variables involved (Mor et al. 2006). Whether the number of leachate samples and pluviothermal factors influenced the physicochemical state of the groundwater in the piezometers was also checked. For this purpose, correlation coefficients were determined for data with a normal distribution, using 

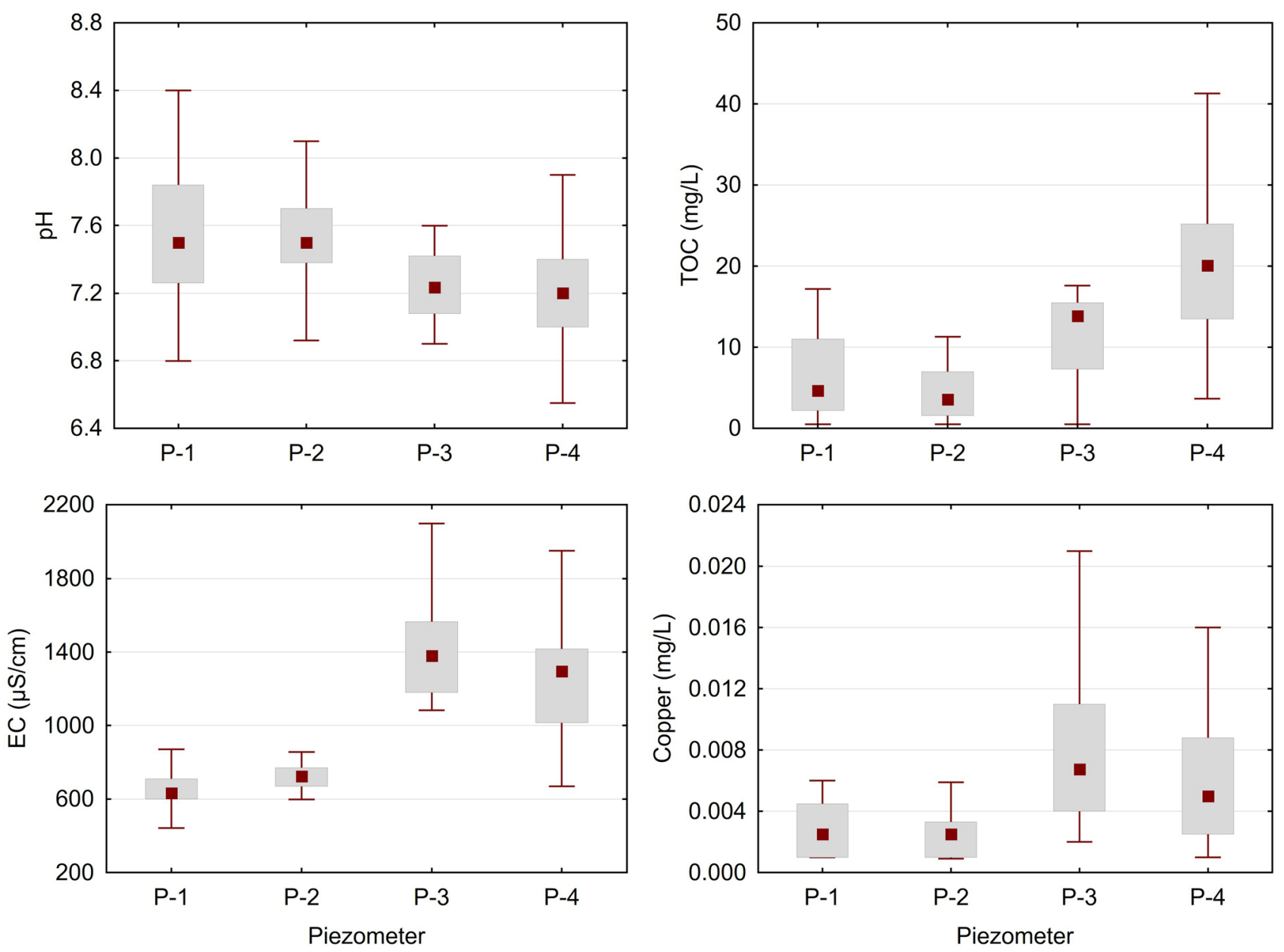

- Median

$25-75 \%$ I Non-outlier range

Fig. 2 Differences of values physicochemical indicators

Pearson's linear correlation coefficient method. If the condition of a normal distribution was not met, the Spearman's rank method was used, where Spearman's $R$ correlation coefficient is the nonparametric equivalent of Pearson's coefficient. A rank correlation reveals any monotonous dependence (also nonlinear). As in the case of parametric correlation, Spearman's $R$ correlation coefficient measures the strength of the dependence between variables, but in this case, a quantitative scale with a normal distribution is no longer required (Jiang et al. 2019; Przydatek and Kanownik 2019).

The analysis of the time trend of physicochemical indicators in the leachate from the landfill and groundwater was carried out using the nonparametric Mann-Kendall test. This test is often used in the analyses of climate change (Sa' adi et al. 2019), hydrology (Ali et al. 2019; Książek et al. 2019) and water quality (Kanownik et al. 2019). The hypothesis on the lack of a data trend on the basis of a nonparametric correlation coefficient is verified. The nonparametric equivalent of the correlation coefficient used in the Mann-Kendall test is the rank correlation coefficient of a data string and a sequence of corresponding time moments, called the Kendall tau coefficient. A positive $\tau_{c}$ indicates a growing tendency, while a negative $\tau_{c}$ suggests a decreasing trend. For this study, a change in the significance level of $\alpha=0.05$ was assumed as a statistically significant increasing or decreasing trend. Statistical analyses were conducted in Statistica 12 by StatSoft (StatSoft Inc. USA; 12 for Windows).

\section{Quality analysis of leachate and groundwater samples and pluviothermal indicators in the landfill site region}

The average quarterly volume of leachate that was produced from the landfill from 2009 to 2016 was $5.655 \mathrm{~m}^{3}$. The average quarterly precipitation was $189.6 \mathrm{~mm}$ and the quarterly air temperature during the research period averaged $9.7^{\circ} \mathrm{C}$ (Table 1). 
$\mathrm{pH}$

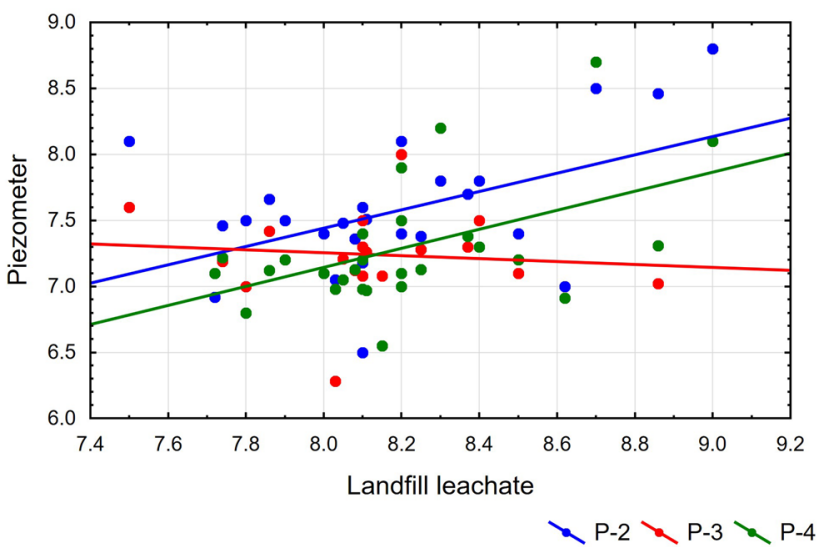

Electrical conductivity $(\mu \mathrm{S} / \mathrm{cm})$

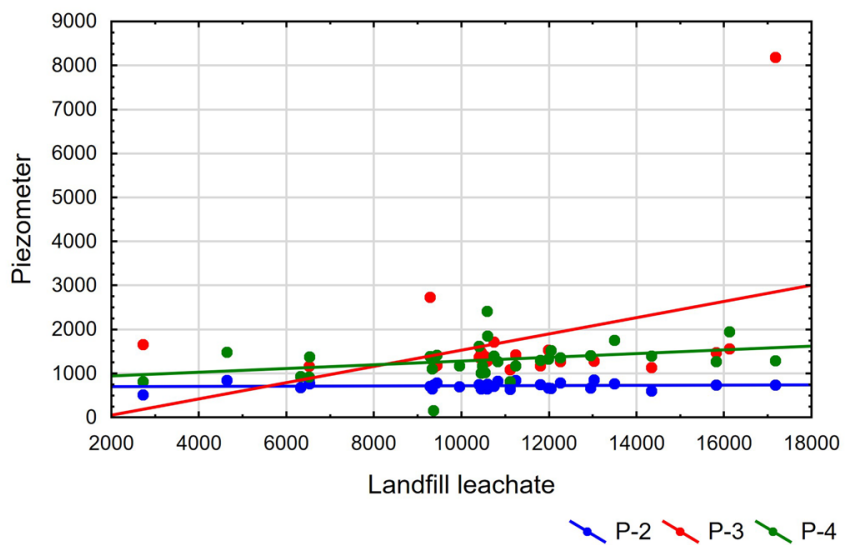

Fig. 3 Correlation between piezometers below landfill site

Table 1 Quarterly amount of leachates from the landfill site and basic meteorological data (quarterly sum of precipitation and average air temperature for the quarter)

\begin{tabular}{lcll}
\hline Parameters & Min-max & Average & $\begin{array}{l}\text { Standard } \\
\text { deviation }\end{array}$ \\
\hline Amount of the leachates $\left(\mathrm{m}^{3}\right)$ & $743-10,231$ & 5655 & 3048 \\
Precipitation $(\mathrm{mm})$ & $64.5-518.4$ & 189.6 & 176.9 \\
Ambient temperature $\left({ }^{\circ} \mathrm{C}\right)$ & $-1.1-22.3$ & 9.7 & 7.06 \\
\hline
\end{tabular}

During the 8 year study period, the average concentration of the tested substances that particularly were harmful to the water environment in the water leached from a municipal landfill site was several times lower than the maximum average normative limit values (Regulation MMEIN 2019a). The leachate $\mathrm{pH}$ reached high values, ranging from 7.5 to 9.0, with an average of 8.2. The concentration of $\mathrm{Hg}$ in water samples was generally less than $5 \mu \mathrm{g} / \mathrm{L}$, with a maximum value of $30 \mu \mathrm{gl}$.

The maximum concentration of $\mathrm{Cd}$ was $36 \mu \mathrm{gl}$, with a maximum value of $200 \mu \mathrm{g} / \mathrm{l}$ (Table 2). Examined leachates
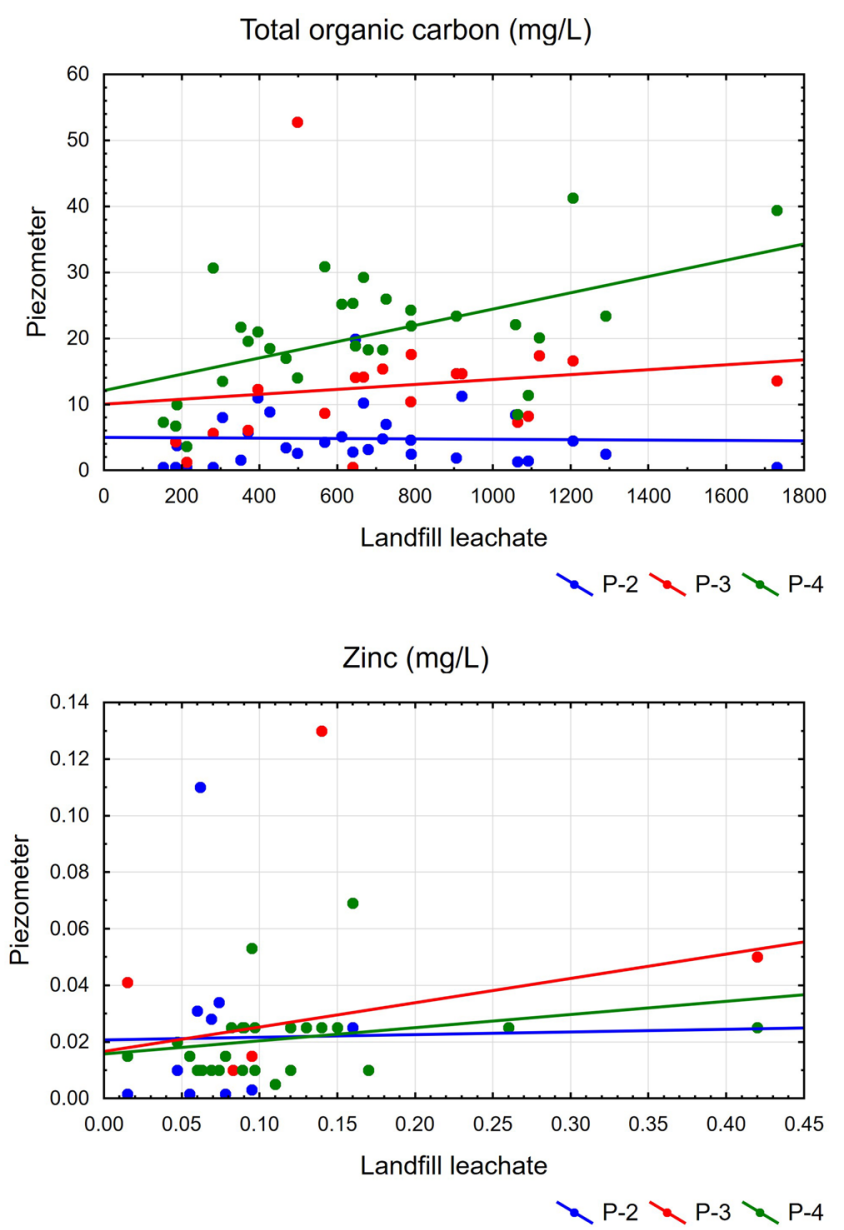

from the landfill site did not meet the requirements for the discharge of wastewater into water bodies or to ground due to the high concentrations of TOC. The minimum concentration of the TOC was $152 \mathrm{mg} / \mathrm{L}$ and the maximum was $1730 \mathrm{mg} / \mathrm{L}$. The average value over the eight years was $679 \mathrm{mg} / \mathrm{L}$, which was more than 22 times higher than the maximum permitted value of $30 \mathrm{mg} / \mathrm{L}$. Leachates from the landfill were characterised by high specific electrical conductivity ranging from 2.721 to $17.170 \mu \mathrm{S} / \mathrm{cm}$. The concentrations of the tested heavy metals were very low. That same low concentration of heavy metals was demonstrated by Przydatek and Kanownik (2019). The highest concentrations were the following: $\mathrm{Zn}$ was $0.42 \mathrm{mg} / \mathrm{L}$, hexavalent $\mathrm{Cr}$ was $0.15 \mathrm{mg} / \mathrm{L}, \mathrm{Cu}$ was $0.06 \mathrm{mg} / \mathrm{L}$ and $\mathrm{Pb}$ was $0.33 \mathrm{mg} / \mathrm{L}$.

The analysis of the groundwater quality in piezometers indicated that most of the determined physicochemical elements meet the standards of very good water quality at Class I (Table 3). During the 8 year testing period of the groundwater samples collected upgradient of the landfill from piezometer P-1, only the concentration of TOC was higher than the limit value permitted for Class I, which qualified the 
Table 2 Statistical parameters describing the pollution indicators in the leachates from the municipal solid-waste landfill site and admissible values

\begin{tabular}{|c|c|c|c|c|}
\hline Pollution indicators & Min-max & Average & $\begin{array}{l}\text { Standard devia- } \\
\text { tion }\end{array}$ & $\begin{array}{l}\text { The highest admissible values in } \\
\text { accordance with Regulation MMEIN } \\
\text { (2019a) }\end{array}$ \\
\hline \multicolumn{5}{|c|}{ Substance especially harmful to the aquatic environment } \\
\hline Mercury $(\mu \mathrm{g} / \mathrm{L})$ & $0.07-4.4$ & 0.43 & 0.77 & 30 \\
\hline Cadmium $(\mu \mathrm{g} / \mathrm{L})$ & $<1-36$ & 11 & 13 & 200 \\
\hline \multicolumn{5}{|l|}{ Other indicators } \\
\hline $\mathrm{pH}$ & $7.5-9.0$ & 8.2 & - & $6.5-9.0$ \\
\hline TOC (mg/L) & $152-1730$ & 679 & 377 & 30 \\
\hline Zinc (mg/L) & $<0.03-0.42$ & 0.12 & 0.07 & 2 \\
\hline Hexavalent chromium (mg/L) & $<0.01-0.15$ & 0.018 & 0.026 & 0.5 \\
\hline Copper (mg/L) & $<0.005-0.06$ & 0.027 & 0.017 & 0.5 \\
\hline Lead $(\mathrm{mg} / \mathrm{L})$ & $0.003-0.33$ & 0.06 & 0.08 & 0.5 \\
\hline Electrical conductivity $(\mu \mathrm{S} / \mathrm{cm})$ & $2721-17,170$ & 10,711 & 3158 & - \\
\hline PAH $(\mu \mathrm{g} / \mathrm{L})$ & $<0.017-4.42$ & 0.31 & 0.79 & - \\
\hline
\end{tabular}

Table 3 An average values of physicochemical indicators and groundwater quality class in the piezometer above the landfill site

\begin{tabular}{|c|c|c|c|c|c|c|c|c|}
\hline \multirow[t]{3}{*}{ Physicochemical indicators } & \multirow{3}{*}{$\begin{array}{l}\text { Piezometer } \\
\text { P-1 } \\
\text { Min-max }\end{array}$} & \multirow[b]{3}{*}{ Average } & \multicolumn{5}{|c|}{ Limit value in classes (Regulation MMEIN 2019b) } & \multirow[t]{3}{*}{ WHO (2017) } \\
\hline & & & \multirow{2}{*}{$\begin{array}{l}\text { Hydrochemical } \\
\text { background }\end{array}$} & \multirow[t]{2}{*}{ I } & \multirow[t]{2}{*}{ II } & \multirow[t]{2}{*}{ III } & \multirow[t]{2}{*}{ IV } & \\
\hline & & & & & & & & \\
\hline $\mathrm{pH}$ & $6.8-9.5$ & 7.6 & $6.5-8.5$ & $6.5-9.5$ & & & $<6.5$ or $>9.5$ & - \\
\hline TOC (mg/L) & $<1-17.2$ & 6.3 & $1-10$ & 5 & 10 & 10 & 20 & - \\
\hline Electrical conductivity $(\mu \mathrm{S} / \mathrm{cm})$ & $218-870$ & 643 & $200-700$ & 700 & 2500 & 2500 & 3000 & - \\
\hline Hexavalent chromium (mg/L) & $<0.01$ & 0.006 & $0.0001-0.01$ & 0.01 & 0.05 & 0.05 & 0.1 & 0.05 \\
\hline Zinc (mg/L) & $<0.01-0.05$ & 0.022 & $0.005-0.05$ & 0.05 & 0.5 & 1 & 2 & - \\
\hline Cadmium $(\mu \mathrm{g} / \mathrm{L})$ & $<0.2-<1$ & 0.19 & $0.1-0.5$ & 1 & 3 & 5 & 10 & 3 \\
\hline Copper (mg/L) & $<0.002-0.015$ & 0.003 & $0.001-0.02$ & 0.01 & 0.05 & 0.2 & 0.5 & 2 \\
\hline Lead (mg/L) & $<0.002-0.029$ & 0.004 & $0.001-0.01$ & 0.01 & 0.025 & 0.1 & 0.1 & 0.01 \\
\hline Mercury $(\mu \mathrm{g} / \mathrm{L})$ & $<0.05-1.1$ & 0.11 & $0.05-1$ & 1 & 1 & 1 & 5 & 6 \\
\hline PAH $(\mu \mathrm{g} / \mathrm{L})$ & $<0.017-<0.1$ & 0.017 & $0.001-0.1$ & 0.1 & 0.2 & 0.3 & 0.5 & - \\
\hline
\end{tabular}

water as good quality water (Table 3 ). The average specific electrical conductivity was close to the limit value $(700 \mu \mathrm{S} /$ $\mathrm{cm}$ ) for Class I, which was $643 \mu \mathrm{S} / \mathrm{cm}$. By contrast, groundwater from downgradient of the landfill that was sampled from piezometer P-2 was classified as good quality water for Class II due to the high average specific electrical conductivity, which exceeded the limit value by $22 \mu \mathrm{S} / \mathrm{cm}$. The other tested physicochemical parameters were at the level of very good quality water. In piezometers P-3 and P-4, the water was more polluted and of much lower quality. When compared with piezometer P-1, the concentration of TOC increased more than three times, which qualifies the water at Class V (i.e. poor quality water), where the values of the physicochemical elements confirm the significant influence of human activity. The maximum electrical conductivity value $(8.190 \mu \mathrm{S} / \mathrm{cm})$ was significantly higher in $\mathrm{P}$, with the mean of this indicator at 1.757 and $1.282 \mu \mathrm{S} / \mathrm{cm}$ in piezometers $\mathrm{P}-3$ and $\mathrm{P}-4$. The mean $\mathrm{Cu}$ concentration was $0.011 \mathrm{mg} / \mathrm{L}$ in the piezometer P-3, which exceeded the limit value for very good quality water (Class I), classifying the water as Class II. The values of other physicochemical elements were at a low level and did not exceed the limit values of groundwater quality Class I (Table 4). Groundwater quality testing showed that the lead concentration sporadically exceeded the limit value of $0.01 \mathrm{mg} / \mathrm{L}$ for drinking water (WHO 2017).

\section{Comparative statistical analysis}

The comparative statistical analysis of physicochemical indicators in groundwater carried out using the nonparametric Kruskal-Wallis test revealed that, out of the 10 analysis 


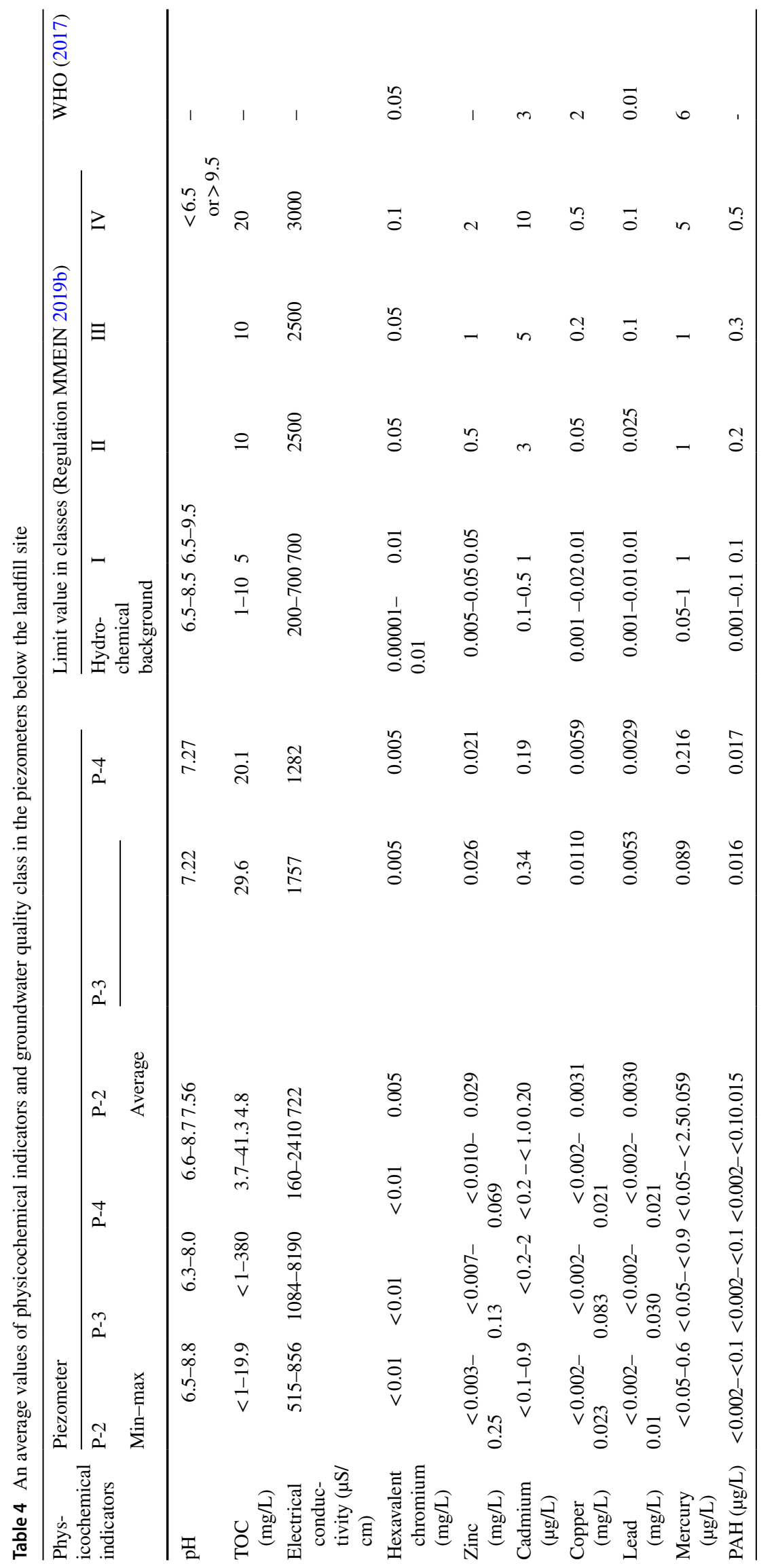


indicators, four $(\mathrm{pH}, \mathrm{TOC}$, electrical conductivity and $\mathrm{Cd}$ ) differed statistically significantly between piezometers at the level of significance of $\alpha=0.001$ (Table 5). The values of the physicochemical elements in the groundwater do not differ between the piezometer (P-1) located upgradient of the landfill and the piezometer (P-2) downgradient of the landfill. The lack of difference in the physicochemical composition of the groundwater between these piezometers may have resulted from the location of piezometer P-2, which was in the central part of the landfill edge (Fig. 1). This may have caused the groundwater that flows directly through footprint of the landfill to bypass this piezometer.

However, differences in the values of physicochemical parameters in the groundwater were found between piezometers $\mathrm{P}-1$ and $\mathrm{P}-2$ and piezometers $\mathrm{P}-3$ and $\mathrm{P}-4$. The $\mathrm{pH}$ values of the water below the landfill in piezometers P-3 and P-4 were statistically significantly lower than in the groundwater at the inflow in piezometers P-1 and P-2. However, the concentration of TOC, the value of the specific electrical conductivity and the concentration of $\mathrm{Cu}$ were statistically significantly higher in the groundwater downgradient of the landfill (Fig. 2). These physicochemical parameters, in addition to the $\mathrm{pH}$, also indicated that leachate from the landfill had caused the deterioration of groundwater quality.

To recognise the effect of the landfill on the physicochemical composition of the groundwater, a correlation analysis was conducted between the water in the piezometers downgradient of the landfill (P-2, P-3 and P-4) and leachate samples from the landfill. A statistically significant correlation (positive correlation) between the groundwater in piezometer $\mathrm{P}-2$ and the leachates was demonstrated for heavy metals (i.e. Cd and $\mathrm{Hg}$ concentrations and a negative correlation for PAHs; Table 6). The groundwater in piezometer P-3 was found to be statistically significantly correlated with the leachate for concentrations of TOC, $\mathrm{Zn}, \mathrm{Cu}, \mathrm{PAHs}$ and EC. In turn, the groundwater in the P-4 piezometer was significantly positively correlated with the leachate for all tested general parameters $(\mathrm{pH}$, TOC and electrical conductivity) and for $\mathrm{Zn}, \mathrm{Pb}$ and $\mathrm{Hg}$ (Fig. 3). The correlation of PAH concentrations exhibits an increase in leachates from the landfill causing a decrease in its concentration in the groundwater in piezometers below the landfill. According to Rosik-Dulewska et al. (2007), the PAH concentration decreases with time.

The analysis of the effect of the volume of leachates and pluviothermal factors (sum of the quarterly precipitation and average quarterly air temperature) on the physicochemical state of groundwater in piezometers revealed that only the air temperature has a statistically significant effect on the concentration of TOC in piezometer P-4. Statistical analysis of groundwater quality indicated a statistically significant upward trend of various concentrations and, in the case of leachate, a downward trend (Table 7). For the groundwater upgradient of the landfill (P-1), an increasing trend was noticeable for four indicators-TOC, EC, $\mathrm{Cu}$ and $\mathrm{Pb}$ concentrations. On the other hand, downgradient of the landfill, five indicators- $\mathrm{pH}, \mathrm{TOC}, \mathrm{EC}, \mathrm{Cu}$ and $\mathrm{Pb}-$ exhibited increasing trends. The concentration of PAHs in the examined groundwater tended to decrease with the groundwater flow. The study of the leachate composition showed a downward trend of the concentrations for four indicator- $\mathrm{Cd}, \mathrm{Cu}, \mathrm{Pb}, \mathrm{Zn}-$ while the $\mathrm{PAH}$ concentration increased. The different trends may be due to the extended time of migration of pollutants or mass transport in the irrigated soil medium (Przydatek and Kanownik, 2019).

Table 5 Comparison of physicochemical indicators values between piezometers using the nonparametric Kruskal-Wallis test

\begin{tabular}{|c|c|c|c|c|c|c|}
\hline \multirow[t]{3}{*}{ Physicochemical indicators } & \multicolumn{4}{|c|}{ Piezometer } & \multicolumn{2}{|c|}{ Results of Kruskal-Wallis test } \\
\hline & $\mathrm{P}-1$ & $\mathrm{P}-2$ & $\mathrm{P}-3$ & $\mathrm{P}-4$ & Test value & Probability test $(p)$ \\
\hline & \multicolumn{6}{|l|}{ Median } \\
\hline $\mathrm{pH}$ & $7.50^{3 ; 4 \mathrm{a}}$ & $7.50^{3 ; 4}$ & $7.24^{1 ; 2}$ & $7.20^{1 ; 2}$ & 17.5 & $<0.001^{\mathrm{b}}$ \\
\hline TOC (mg/L) & $4.6^{3 ; 4}$ & $3.6^{3 ; 4}$ & $13.9^{1 ; 2}$ & $20.1^{1 ; 2}$ & 52.9 & $<0.001$ \\
\hline Electrical conductivity $(\mu \mathrm{S} / \mathrm{cm})$ & $633^{3 ; 4}$ & $725^{3 ; 4}$ & $1.381^{1 ; 2}$ & $1,296^{1 ; 2}$ & 76.2 & $<0.001$ \\
\hline Hexavalent chromium (mg/L) & 0.005 & 0.005 & 0.005 & 0.005 & 2.77 & 0.43 \\
\hline Zinc (mg/L) & 0.025 & 0.025 & 0.025 & 0.025 & 0.88 & 0.83 \\
\hline Cadmium $(\mu \mathrm{g} / \mathrm{L})$ & 0.15 & 0.15 & 0.15 & 0.15 & 3.44 & 0.33 \\
\hline Copper (mg/L) & $0.003^{3 ; 4}$ & $0.003^{3 ; 4}$ & $0.007^{1 ; 2}$ & $0.005^{1 ; 2}$ & 29.0 & $<0.001$ \\
\hline Lead (mg/L) & 0.002 & 0.002 & 0.002 & 0.002 & 1.90 & 0.59 \\
\hline Mercury $(\mu \mathrm{g} / \mathrm{L})$ & 0.025 & 0.025 & 0.025 & 0.025 & 1.51 & 0.68 \\
\hline PAH $(\mu \mathrm{g} / \mathrm{L})$ & 0.009 & 0.009 & 0.009 & 0.013 & 0.32 & 0.96 \\
\hline
\end{tabular}

${ }^{\text {a }}$ The digits in the upper index mean a piezometer in which the parameter values are significantly different for multiple (two-sided) comparisons of the average ranks

${ }^{\mathrm{b}}$ Statistical values in italic mean statistically significant differences at $p<0.001$ 
Table 6 Correlation dependence of physicochemical indicators between water in piezometers P-2, P-3 and P-4 and leachates from the landfill site

\begin{tabular}{|c|c|c|c|c|}
\hline Physicochemical indicators & Piezometer & $\mathrm{R}$ spearman & $t(n-2)$ & Test probability $(p)$ \\
\hline \multirow[t]{3}{*}{$\mathrm{pH}$} & $\mathrm{P}-2$ & 0.327 & 1.83 & 0.08 \\
\hline & $\mathrm{P}-3$ & -0.012 & -0.053 & 0.96 \\
\hline & $\mathrm{P}-4$ & 0.39 & 2.27 & $0.03^{a}$ \\
\hline \multirow[t]{3}{*}{ TOC (mg/L) } & $\mathrm{P}-2$ & 0.10 & 0.512 & 0.61 \\
\hline & P-3 & 0.51 & 2.52 & 0.02 \\
\hline & P-4 & 0.45 & 2.7 & 0.01 \\
\hline \multirow[t]{3}{*}{ Electrical conductivity $(\mu \mathrm{S} / \mathrm{cm})$} & $\mathrm{P}-2$ & 0.018 & 0.095 & 0.92 \\
\hline & $\mathrm{P}-3$ & 0.52 & 2.74 & 0.021 \\
\hline & P-4 & 0.36 & 2.07 & 0.048 \\
\hline \multirow[t]{3}{*}{ Hexavalent chromium (mg/L) } & $\mathrm{P}-2$ & - & & \\
\hline & $\mathrm{P}-3$ & - & & \\
\hline & P-4 & - & & \\
\hline \multirow[t]{3}{*}{ Zinc (mg/L) } & P-2 & 0.17 & 0.93 & 0.40 \\
\hline & $\mathrm{P}-3$ & 0.57 & 3.00 & 0.007 \\
\hline & P-4 & 0.49 & 2.97 & 0.006 \\
\hline \multirow[t]{3}{*}{ Cadmium $(\mu \mathrm{g} / \mathrm{L})$} & $\mathrm{P}-2$ & 0.12 & 0.68 & 0.50 \\
\hline & P-3 & -0.03 & -0.14 & 0.89 \\
\hline & P-4 & 0.33 & 1.91 & 0.07 \\
\hline \multirow[t]{3}{*}{ Copper (mg/L) } & $\mathrm{P}-2$ & -0.32 & -1.80 & 0.08 \\
\hline & P-3 & -0.44 & -2.58 & 0.02 \\
\hline & P-4 & -0.031 & -0.137 & 0.89 \\
\hline \multirow[t]{3}{*}{ Lead (mg/L) } & $\mathrm{P}-2$ & 0.055 & 0.291 & 0.77 \\
\hline & P-3 & 0.097 & 0.423 & 0.68 \\
\hline & P-4 & 0.153 & 0.821 & 0.42 \\
\hline \multirow[t]{3}{*}{ Mercury $(\mu \mathrm{g} / \mathrm{L})$} & $\mathrm{P}-2$ & 0.521 & 3.23 & 0.003 \\
\hline & P-3 & 0.309 & 1.42 & 0.17 \\
\hline & P-4 & 0.500 & 3.06 & 0.005 \\
\hline \multirow[t]{3}{*}{ PAH $(\mu \mathrm{g} / \mathrm{L})$} & $\mathrm{P}-2$ & -0.69 & -5.05 & $<0.001$ \\
\hline & P-3 & -0.456 & -2.23 & 0.038 \\
\hline & P-4 & -0.575 & -3.72 & $<0.001$ \\
\hline
\end{tabular}

${ }^{a}$ Italic value of statistics means that the relationship is statistically significant at $p<0.05$

\section{Discussion}

Table 7 Time trends of examined parameters quality of leachate and groundwater

\begin{tabular}{|c|c|c|c|c|c|}
\hline \multirow[t]{2}{*}{ Physicochemical indicators } & \multirow[t]{2}{*}{ Leachate } & \multicolumn{4}{|c|}{ Piezometer } \\
\hline & & $\mathrm{P}-1$ & $\mathrm{P}-2$ & P-3 & $\mathrm{P}-4$ \\
\hline $\mathrm{pH}$ & & & & $\uparrow$ & $\uparrow$ \\
\hline TOC (mg/L) & & $\uparrow$ & $\uparrow$ & & \\
\hline Electrical conductivity $(\mu \mathrm{S} / \mathrm{cm})$ & & $\uparrow$ & $\uparrow$ & $\downarrow$ & \\
\hline Hexavalent chromium (mg/L) & & & & & \\
\hline Zinc (mg/L) & $\downarrow$ & $\downarrow$ & & $\downarrow$ & $\downarrow$ \\
\hline Cadmium $(\mu \mathrm{g} / \mathrm{L})$ & $\downarrow$ & & & & \\
\hline Copper (mg/L) & $\downarrow$ & $\uparrow$ & $\uparrow$ & $\uparrow$ & $\uparrow$ \\
\hline Lead (mg/L) & $\downarrow$ & & & & \\
\hline Mercury $(\mu \mathrm{g} / \mathrm{L})$ & & $\uparrow$ & $\uparrow$ & $\uparrow$ & $\uparrow$ \\
\hline PAH $(\mu \mathrm{g} / \mathrm{L})$ & $\uparrow$ & $\downarrow$ & $\downarrow$ & $\downarrow$ & $\downarrow$ \\
\hline
\end{tabular}

A statistically significant upward $(\uparrow)$ and downward $(\downarrow)$ trend
Leachate is still one of the most serious dangers in landfills (Przydatek 2019a). The analysis of the composition of leachate water from a landfill that has been in use for more than 20 years with a waste accumulation of more than $10 \mathrm{Mg}$ per day exhibited high variability over time.

In the raw leachate samples from the tested municipal landfill, $\mathrm{pH}$ peaked at 9.0 with an average of 8.2. This indicates that the leachate comes from a mature landfill, which has been in use for over ten years (Nájera-Aguilar et al., 2019) and is in the methanogenic phase (Wdowczyk and Szymańska-Pulikowska 2019). In turn, low concentrations of $\mathrm{Hg}$ at $5 \mu \mathrm{g} / \mathrm{L}$ and $\mathrm{Cd}$ at $36 \mu \mathrm{g} / \mathrm{L}$ were recorded in the investigated leachate.

Similarly, low $\mathrm{Hg}$ concentrations in tested leachate samples were found by Talalaj (2013). Przydatek and Kanownik (2019) also found a low Cd concentration (mean $1.05 \mu \mathrm{g} / \mathrm{L}$ ), 
which was considered a factor in the deterioration of the groundwater quality below the landfill. In addition, concentrations of other heavy metals (e.g. $\mathrm{Zn}, \mathrm{Cu}$ and $\mathrm{Pb}$ ) in the tested leachates were low with a simultaneous downward trend. The highest concentration of $\mathrm{Zn}$ was $0.42 \mathrm{mg} / \mathrm{L}$, which differed from that found by Boateng et al. (2019) in Africa. Kanownik and Policht-Latawiec (2016) considered the low concentration of heavy metals (i.e. $\mathrm{Cr}^{+6}, \mathrm{Ni}$, and $\mathrm{Pb}$ ), to be a characteristic of old municipal landfills. Abiriga et al. (2020) identified the age of waste as the most significant factor in groundwater contamination in the vicinity of a landfill.

Significant deterioration of leachate quality was caused by an increased concentration of TOC at an average value of $679 \mathrm{mg} / \mathrm{L}$. Gellert (2000) demonstrated that this indicator at concentrations between 1.44 and $74.4 \mathrm{mg} / \mathrm{L}$ is toxic. Another tested indicator, electrical conductivity as a measure of salinity in the tested leachates, reached high values in the range of 2.721 to $17.170 \mu \mathrm{S} / \mathrm{cm}$. Slightly lower maximum electrical conductivity values in the tested leachates in Serbia were obtained by Tenodi et al. (2020).

The deterioration of the groundwater quality at the outflow was primarily influenced by the high average electrical conductivity values of 1.757 and $1.282 \mu \mathrm{S} / \mathrm{cm}$ and the average $\mathrm{Cu}$ concentration of $0.011 \mathrm{mg} / \mathrm{L}$. Gupta and Paulraj (2017) classified $\mathrm{Cu}$ as a particularly toxic element, which was demonstrated based on a statistical analysis. The high value of specific electrical conductivity in groundwater (Brindha et al. 2014; Maiti et al. 2016; Deshmukh and Aher 2016) has been linked by some researchers to the effect of landfill leachate. The deterioration of groundwater quality near the analysed landfill site was also significantly affected by a more than threefold increase in TOC concentration at the outflow and by the increased value of this indicator, which generally affected their classification as the worst, at Class V. Huan-Jung et al. (2006) also discovered high concentrations of both electrical conductivity and TOC based on the studies of water in the area of landfills.

A noticeable increase in the concentration of PAHs in the tested leachates is related to anthropogenic sources, particularly from the incomplete combustion of fuels (Malakahmad et al. 2016). Many compounds from the PAH group exhibit carcinogenic properties and a strong mutagenic effect (Kubiak 2013). However, a noticeable decrease in the concentration of PAHs in groundwater below the landfill results from the degradation of its compounds in the landfill and volatilisation by landfill gas (Talalaj and Biedka 2016).

The deterioration of water quality below the landfill was also indicated by significantly higher concentrations of physical and chemical parameters, particularly with specific electrical conductivity, TOC and $\mathrm{Cu}$, which had noticeable uptrends. Koda et al. (2017) also showed high concentrations of TOC in groundwater contaminated in the area of the landfill through contact with organic substances. These waters were also significantly correlated with the leachate based on electrical conductivity, $\mathrm{Cu}$ and TOC indications. A significant correlation between these indicators and groundwater pollution in the landfill area was demonstrated by Aderemi et al. (2011) and Krčmar et al. (2018). Both Zn and $\mathrm{Hg}$ could also affect water pollution. Przydatek showed the deterioration of water quality in the landfill area as a result of elevated $\mathrm{Zn}$ concentrations by comparison with natural background levels (2021). The strongest correlation between the chemical composition of leachate samples and groundwater occurred in groundwater immediately downgradient of the landfill site (Boateng et al. 2019). This confirms that the spatial extent of groundwater hazard through the source of contamination from a landfill is intrinsically linked to the penetration of the liquid phase and the composition of leachates (Przydatek 2012). Przydatek and Kanownik (2019), based on an integrated model of water environment hazard with the use of electrical conductivity, TOC and Cd indicators, demonstrated that the course of the negative effect of a landfill site on groundwater and, indirectly, on surface water depends on local geological and hydrogeological conditions and processes taking place in the groundwater environment.

Another factor rarely used to identify the effect on the processes in a waste deposit is the ambient temperature. Research in this area was also conducted by Rowe and Arnepalli (2008), but they did not reach a binding conclusion in this respect.

A study of leachates from a landfill that has been in use for 80 years has shown that an interaction occurs between leachates and groundwater. Some researchers (e.g. Han et al. 2016) found that the most intense groundwater pollution occurs near landfills that are less than 20 years old. The reason for the negative influence could be the limited capacity of leachate treatment systems to treat the produced leachate. This appears to be especially the case after a period of over 20 years of use, which Rowe (2005) also noted.

Another reason for the deterioration could be the leachate leakage through the geomembrane due to manufacturing and construction defects or vapour diffusion through the lining (Pantini et al. 2014; Grugnaletti et al. 2016). The leakage could also cause negative impact on aquatic environments near the landfill, which can be affected by leachate, even from lined landfill facilities. The above-mentioned factors may also result from unintentional failures at the landfill (Ciuła et al. 2020).

The demonstrated pollutants migrating from the landfill to the groundwater may be present in the immediate vicinity or even up to hundreds of metres away (Abiriga et al. 2020). Koda (2009) demonstrated that the migration of pollutants depends on geological conditions and may favour the transport of water and the substances it carries or may stop the transport of water from the landfill site altogether. 


\section{Conclusions}

Based on an examines of the leachate composition and groundwater quality near a lined landfill during eight years of its use, the following conclusions were drawn:

- The analysis of the leachate composition and groundwater quality revealed a significant time variability of the physicochemical composition.

- Significant factors influencing the deterioration of the groundwater quality downgradient of the landfill included: (1) more than threefold increase in TOC concentration, which generally qualified the water as being of poor quality; (2) a high electrical conductivity value reaching $8.190 \mu \mathrm{S} / \mathrm{cm}$; (3) a high $\mathrm{Cu}$ concentration, which were statistically significantly higher than in groundwater hydraulically upgradient of the landfill site; and (4) upward concentration trend in groundwater from inflow to outflow in concentrations of EC, TOC and $\mathrm{Cu}$.

- A significant correlation between TOC, electrical conductivity, $\mathrm{Zn}, \mathrm{Cu}, \mathrm{Pb}, \mathrm{Hg}$ and PAHs between leachate samples from the landfill and groundwater in the area is the result of the movement of leaching of contaminants into groundwater in the aeration zone.

- The progressing ageing process of the landfilled waste was indicated by low concentrations of heavy metals $(\mathrm{Hg}$, $\mathrm{Cu}, \mathrm{Cd}, \mathrm{Pb}$ and $\mathrm{Zn}$ ) and their decreasing trend.

Acknowledgements The authors of the study would like to thank the operator of the examined landfill site for making it available for research purposes.

Author contribution I declare that the contribution (50\%) to the creation of the mentioned publication included the preparation of a hypothesis, literature review, interpretation of the results and their discussion with conclusions, preparation of the manuscript for printing, translation of the manuscript text into English: Grzegorz Przydatek. I declare that my contribution $(50 \%)$ to the publication included the preparation of research results and carrying out research, selection of statistical methodology and tools, analysis of the results, including the statistical one, preparation and development of the graphic part of the work, substantive verification of the work: łodzimierz Kanownik.

\section{Funding Not applicable.}

Availability of data and materials The datasets used and/or analysed during the current study are available from the corresponding author on reasonable request. All data generated or analysed during this study are included in this published article (and its supplementary information files).

\section{Declarations}

Conflict of interest Not applicable.

Ethics approval Not applicable.
Consent to Participate Not applicable.

Consent to Publish Not applicable.

Open Access This article is licensed under a Creative Commons Attribution 4.0 International License, which permits use, sharing, adaptation, distribution and reproduction in any medium or format, as long as you give appropriate credit to the original author(s) and the source, provide a link to the Creative Commons licence, and indicate if changes were made. The images or other third party material in this article are included in the article's Creative Commons licence, unless indicated otherwise in a credit line to the material. If material is not included in the article's Creative Commons licence and your intended use is not permitted by statutory regulation or exceeds the permitted use, you will need to obtain permission directly from the copyright holder. To view a copy of this licence, visit http://creativecommons.org/licenses/by/4.0/.

\section{References}

Abd El-Salam MM, Abu-Zuid GI (2015) Impact of landfill leachate on the groundwater quality: a case study in Egypt. J Adv Res 6(4):579-586. https://doi.org/10.1016/j.jare.2014.02.003

Abiriga D, Vestgarden LS, Klempe H (2020) Groundwater contamination from a municipal landfill effect of age, landfill closure, and season on groundwater chemistry. Sci Total Environ 737:140307. https://doi.org/10.1016/j.scitotenv.2020.140307

Aderemi AO, Oriaku AV, Adewumi GA, Otitoloju AA (2011) Assessment of groundwater contamination by leachate near a municipal solid waste landfill. Afr J Environ Sci Technol 5(11):933-940. https://doi.org/10.5897/AJEST11.272

Ali R, Kuriqi A, Abubaker S, Kisi O (2019) Long-term trends and seasonality detection of the observed flow in Yangtze River using Mann-Kendall and Sen's innovative trend method. Water 11(9):1855. https://doi.org/10.3390/w11091855

Almeida IS, Oliveira MDR, Silva JBB, Coelho NMM (2016) Suitable extraction of soils and sediments for mercury species and determination combined with the cold vapor generation atomic absorption spectrometry technique. Microchem J 124:326-330. https://doi.org/10.1016/j.microc.2015.09.007

APHA (2007) Standard method for the examination of water and wastewater. American public health association, Washington, USA

Atta M, Yaacob WZW, Jaafar OB (2015) The potential impact of leachate-contaminated groundwater of an ex-landfill site at Taman Beringin Kuala Lumpur, Malaysia. Environ Earth Sci 73:39133923. https://doi.org/10.1007/s12665-014-3675-x

Aziz SQ, Bashir MJK, Aziz HA, Mojiri A, Amr SSA, Maulood YI (2018) Statistical analysis of municipal solid waste landfill leachate characteristics in different countries. Zanco J Pure Appl Sci 30(6):85-96. https://doi.org/10.21271/ZJPAS.30.6.8

Barbieri M, Sappa G, Vitale S, Parisse B, Battistel M (2014) Soil control of trace metals concentrations in landfill: a case study of the largest landfill in Europe, Malagrotta, Rome. J Geochem Explor 143:146-154. https://doi.org/10.1016/j.gexplo.2014.04.001

Baun DL, Christensen TH (2004) Speciation of heavy metals in landfill leachate: a review. Waste Manag Res 22:3-23. https://doi.org/10. 1177/0734242X04042146

Boateng TK, Opoku F, Akoto O (2019) Heavy metal contamination assessment of groundwater quality: a case study of Oti landfill site, Kumasi. Appl Water Sci 9:33. https://doi.org/10.1007/ s13201-019-0915-y

Brindha K, Neena Vaman KV, Srinivasan K, Sathis Babu M, Elango L (2014) Identification of surface water-groundwater interaction 
by hydrogeochemical indicators and assessing its suitability for drinking and irrigational purposes in Chennai, Southern India. Appl Water Sci 4(2):159-174. https://doi.org/10.1007/ s13201-013-0138-6

Chen PH (2006) Assessment of leachates from sanitary landfills: Impact of age, rainfall, and treatment. Environ Int 22(2):225-237. https://doi.org/10.1016/0160-4120(96)00008-6

Ciuła J, Kozik V, Generowicz A, Gaska K, Bak A, Padzior M, Barbusiński K (2020) Emission and neutralization of methane from a municipal landfill-parametric analysis. Energies 13(23):6254. https://doi.org/10.3390/en13236254

Council 1999/31/EC of 26 April 1999 on the landfill of waste (OJ L $182,16.7 .1999)$

Deshmukh KK, Aher SP (2016) Assessment of the impact of municipal solid waste on groundwater quality near the Sangamner city using GIS approach. Water Resour Manag 30:2425-2443. https://doi. org/10.1007/s11269-016-1299-5

Faitli J, Magyara T, Erdélyi A, Murányic A (2015) Characterization of thermal properties of municipal solid waste landfills. Waste Manag 36:213-221. https://doi.org/10.1016/j.wasman.2014.10. 028

Farzaneh G, Khorasani N, Ghodousi J, Panahi M (2021) Assessment of surface and groundwater resources quality close to municipal solid waste landfill using multiple indicators and multivariate statistical methods. Int J Environ Res. https://doi.org/10.1007/ s41742-020-00307-9

Gellert G (2000) Relationship between summarizing chemical parameters like AOX, TOC, TNb, and toxicity tests for effluents from the chemical production. Bull Environ Contam Toxicol 65(4):508513. https://doi.org/10.1007/s001280000153

Grugnaletti M, Pantini S, Verginelli I, Lombardi F (2016) An easyto-use tool for the evaluation of leachate production at landfill sites. Waste Manag 55:204-219. https://doi.org/10.1016/j.wasman.2016.03.030

Gupta A, Paulraj R (2017) Leachate composition and toxicity assessment: an integrated approach correlating physicochemical parameters and toxicity of leachates from MSW landfill in Delhi. Environ Technol 38(13-14):1-7. https://doi.org/10.1080/09593330. 2016.1238515

Gworek B, Dmuchowski W, Koda E, Marecka M, Baczewska AH, Brągoszewska P, Sieczka A, Osiński P (2016) Impact of the municipal solid waste Łubna landfill on environmental pollution by heavy metals. Water 8(10):470. https://doi.org/10.3390/w8100 470

Han Z, Ma H, Shi G, He L, Wei L, Shi Q (2016) A review of groundwater contamination near municipal solid waste landfill sites in China. Sci Total Environ 569:1255-1264. https://doi.org/10. 1016/j.scitotenv.2016.06.201

Hirschberg K-JB (1993) Municipal wastes disposal in perth and its impact on groundwater quality. Geol Surv Western Australian Tech Rep 34:97-109

Huan-Jung F, Shu HY, Yang HS, Chen WC (2006) Characteristics of landfill leachates in central Taiwan. Sci Total Environ 361(13):25-37. https://doi.org/10.1016/j.scitotenv.2005.09.033

Ilies P, Mavinic DS (2001) The effect of decreased ambient temperature on the biological nitrification and denitrification of a high ammonia landfill leachate. Water Res 35(8):2065-2072. https://doi.org/ 10.1016/S0043-1354(00)00477-2

Jiang Y, Li R, Yang Y, Yu M, Xi B, Li M, Xu Z, Gao S, Young Ch (2019) Migration and evolution of dissolved organic matter in landfill leachate-contaminated groundwater plume. Resour Conserv Recycl 151:104463. https://doi.org/10.1016/j.resconrec.2019. 104463

Kanownik W, Policht-Latawiec A (2016) Impact of municipal landfill site on water quality in the Włosanka stream. J Ecol Eng 17(4):57-64. https://doi.org/10.12911/22998993/63961
Kanownik W, Policht-Latawiec A, Fudała W (2019) Nutrient pollutants in surface water-assessing trends in drinking water resource quality for a regional city in Central Europe. Sustainability 11(7):1988. https://doi.org/10.3390/su11071988

Koda E (2009) Assessment of efficiency of the old landfill protection system based on transport modelling and monitoring research. Conference: 17th international conference on soil mechanics and geotechnical engineering, 3 , Alexandria.

Koda E, Miszkowska A, Sieczka A (2017) Levels of organic pollution indicators in groundwater at the old landfill and waste management site. Appl Sci 7(6):638. https://doi.org/10.3390/app7060638

Krčmar D, Tenodi S, Grba N, Kerkez D, Watson M, Rončević S, Dalmacija B (2018) Preremedial assessment of the municipal landfill pollution impact on soil and shallow groundwater in Subotica, Serbia. Sci Total Environ 615:1341-1354. https://doi. org/10.1016/j.scitotenv.2017.09.283

Książek L, Woś A, Florek J, Wyrębek M, Młyński D, Wałęga A (2019) Combined use of the hydraulic and hydrological methods to calculate the environmental flow: Wisloka river, Poland: case study. Environ Monit Assess 191(4):254. https://doi.org/ 10.1007/s10661-019-7402-7

Kubiak MS (2013) Wielopierścieniowe węglowodory aromatyczne (WWA) - ich występowanie w środowisku i w żywności. Probl Hig Epi-Demiol 94(1):31-36 (in polish)

Longe E, Balogun MR (2009) Groundwater Quality Assessment near a Municipal Landfill, Lagos, Nigeria. Res J Appl Sci Eng Technol 2(1):39-44

MacDonald AM, Calow RC (2009) Developing groundwater for secure rural water supplies in Africa. Desalination 248:546556. https://doi.org/10.1016/j.desal.2008.05.100

Maiti SK, De S, Hazra T, Debsarkar A, Dutta A (2016) Characterization of leachate and its impact on surface and groundwater quality of a closed dumpsite - a case study at Dhapa, Kolkata, India. Procedia Environ Sci 35:391-399. https://doi.org/10. 1016/j.proenv.2016.07.019

Malakahmad A, Law MX, Ng KW, Manan TS (2016) The fate and toxicity assessment of polycyclic aromatic hydrocarbons (PAHs) in water streams of Malaysia. Procedia Engineering 148:806-811. https://doi.org/10.1016/j.proeng.2016.06.572

Mor S, Ravindra K, Dahiya RP, Chandra A (2006) Leachate characterization and assessment of groundwater pollution near municipal solid waste landfill site. Environ Monit Assess 118:435-456. https://doi.org/10.1007/s10661-006-1505-7

Naveen BP, Mahaparta DM, Sitharam TG, Sivapullaiah PV, Ramachandra TV (2017) Physico-chemical and biological characterization of urban municipal landfill leachate. Environ Pollut 220(A):1-12. https://doi.org/10.1016/j.envpol.2016.09.002

Pantini S, Verginelli I, Lombardi F (2014) A new screening model for leachate production assessment at landfill sites. Int $\mathbf{J}$ Environ Sci Technol 11:1503-1516. https://doi.org/10.1007/ s13762-013-0344-7

Patil C, Narayanakar S, Virupakshi A (2013) Assessment of groundwater quality around solid waste landfill area-a case study. Int J Innov Res Sci Eng Technol 2(7):3131-3136

Przydatek G (2012) Evaluation of the efficiency of the system of dehydration operated landfill of municipal waste. Infrastructure and Ecology of Rural Areas, 2/III/2012, pp 217-226 (in polish)

Przydatek G (2019a) Multi-indicator analysis of the influence of old municipal landfill sites on the aquatic environment: case study. Environ Monit Assess 191:773. https://doi.org/10.1007/ s10661-019-7814-4

Przydatek G (2019b) Analysis of the toxicity in leachate at selected municipal landfill sites. The Institute for Sustainable Technologies (ISBN 978-83-7789-564-1, 1-152 (in polish))

Przydatek G (2019c) The analysis of the possibility of using biological tests for assessment of toxicity of leachate from an active 
municipal landfill. Environ Toxicol Pharmacol 67:94-101. https://doi.org/10.1016/j.etap.2019.01.013

Przydatek G (2021) Using advanced statistical tools to assess the impact of a small landfill site on the aquatic environment. Environ Monit Assess 193:71. https://doi.org/10.1007/ s10661-021-08850-4

Przydatek G, Kanownik W (2019) Impact of small municipal solid waste landfill on groundwater quality. Environ Monit Assess 191(3):169. https://doi.org/10.1007/s10661-019-7279-5

Regadío M, De Soto IS, Rodríguez-Rastrero M, Ruiz AI, Gismera MJ, Cuevas J (2013) Processes and impacts of acid discharges on a natural substratum under a landfill. Sci Total Environ 463:1049_ 1059. https://doi.org/10.1016/j.scitotenv.2013.06.047

Regulation of the Minister of Environment of 30 April 2013 on landfills (2013) (journal of laws 2013 item 523)

Regulation of the Minister of Maritime Economy and Inland Navigation of 12 July 2019 on substances particularly harmful to the aquatic environment and the conditions to be met when discharging sewage into waters or ground, as well as discharging rainwater or meltwater into waters or for water devices (2019a) (journal of laws 2019, item 1311)

Regulation of the Minister of Maritime Economy and Inland Navigation of 11 October 2019 on criteria and method of assessment of the status of groundwater bodies (2019b) (journal of laws 2019, item 2148)

Rosik-Dulewska C, Karwaczyńska U, Ciesielczuk T (2007) Migration of PAHs from unsealed landfill to groundwaters. Rocznik Ochrona Środowiska 9:335-343

Rowe RK (2005) Long-term performance of contaminant barrier systems. Geotechnique 55(9):631-678. https://doi.org/10.1680/geot. 2005.55.9.631

Rowe RK, Arnepalli DN (2008) The effects of landfill temperature on the contaminant transport through a composite liner. In: 12th international conference of international association for computer methods and advances in geomechanics, pp 2398-2404

Sa'adi Z, Shahid S, Ismail T, Chung ES, Wang XJ (2019) Trends analysis of rainfall and rainfall extremes in Sarawak, Malaysia using modified Mann-Kendall test. Meteorol Atmos Phys 131(3):263277. https://doi.org/10.1007/s00703-017-0564-3

Salem Z, Hamouri K, Djemaa R, Allia K (2008) Evaluation of landfill leachate pollution and treatment. Desalination 220:108-114. https://doi.org/10.1016/j.desal.2007.01.026
Sari H, Yetilmezsoy K, Ilhan F, Yazici S, Kurt U, Apaydin O (2013) Fuzzy-logic modeling of Fenton's chemical oxidation process treating three types of landfill leachates. Environ Sci Pollut Res 20(6):4235-4253. https://doi.org/10.1007/s11356-012-1370-6

Singh H, Raju NJ, Gossel W, Wycisk P (2016) Assessment of pollution potential of leachate from the municipal solid waste disposal site and its impact on groundwater quality, Varanasi environs, India. Arabian J Geosci 9(2):131. https://doi.org/10.1007/ s12517-015-2131-x

Statistics Poland (2019) https://bdl.stat.gov.pl/BDL/dane/teryt/tablica. Accessed 29.07.2020.

Talalaj IA (2013) Groundwater and surface water quality assessment near the closed municipal landfill. J Ecol Eng 14(3):89-98. https:// doi.org/10.5604/2081139X.1056572

Talalaj IA, Biedka P (2016) Use of the landfill water pollution index (LWPI) for groundwater quality assessment near the landfill sites. Environ Sci Pollut Res 23:24601-24613

Tenodi S, Krčmar D, Agbaba J, Zrnić K, Radenović M, Ubavin D, Dalmacija B (2020) Assessment of the environmental impact of sanitary and unsanitary parts of a municipal solid waste landfill. J Environ Manag 258:110019. https://doi.org/10.1016/j.jenvman. 2019.110019

Wdowczyk A, Szymańska-Pulikowska A (2019) Differences in the composition of leachate from active and non-operational municipal waste landfills in Poland. Water 12(11):3129. https://doi.org/ $10.3390 / w 12113129$

WHO (2017) Drinking water parameter cooperation project. support to the revision of annex I council directive $98 / 83 / \mathrm{EC}$ on the quality of water intended for human consumption (drinking water directive).

Xie S, Ma Y, Strong PJ, Clarke WP (2015) Fluctuation of dissolved heavy metal concentrations in the leachate from anaerobic digestion of municipal solid waste in commercial scale landfill bioreactors: the effect of $\mathrm{pH}$ and associated mechanisms. J Hazard Mater 299:577-583. https://doi.org/10.1016/j.jhazmat.2015.07.065

Publisher's Note Springer Nature remains neutral with regard to jurisdictional claims in published maps and institutional affiliations. 